\title{
Cell cycle regulators and their abnormalities in breast cancer
}

\author{
P L Fernández, P Jares, M J Rey, E Campo, A Cardesa
}

\begin{abstract}
One of the main properties of cancer cells is their increased and deregulated proliferative activity. It is now well known that abnormalities in many positive and negative modulators of the cell cycle are frequent in many cancer types, including breast carcinomas. Abnormalities such as defective function of the retinoblastoma gene and cyclin-dependent kinase inhibitors (for example, p16, p21, and p27), as well as upregulation of cyclins, are often seen in breast tumours. These abnormalities are sometimes coincidental, and newly described interplays between them suggest the existence of a complex regulatory web in the cell cycle.

(F Clin Pathol: Mol Pathol 1998;51:305-309)
\end{abstract}

Keywords: cell cycle regulators; breast cancer; cyclins; cyclin dependent kinases; retinoblastoma gene product

Malignant cells, like their normal counterparts, progress through a life cycle that encompasses several consecutive phases, each of which must be completed before entering the next one. These phases are $\mathrm{G} 1$, in which the cells prepare their machinery for replication; $S$ phase in which duplication of genomic information occurs; G2, an intervening phase; and $M$ phase, in which the actual division (and therefore proliferation) takes place. Cells thus generated can either start a new cycle or remain in a state of quiescence, known as G0 phase. Although this scheme seems to be common to both normal and tumour cells, one of the most important characteristics of the latter is their increased proliferative capability, most likely resulting from impaired control of the regulatory elements of the cell cycle. Indeed, cell cycle regulators are subject to strict control in normal cells and their activities fluctuate according to external stimuli, whereas in neoplastic cells a variable degree of independence from such stimuli seems to emerge.

\section{Regulation of the cell cycle}

The cell cycle has several checkpoints that are controlled by an increasingly understood complex system of modulators, among which the retinoblastoma gene product ( $\mathrm{pRB})$, cyclins, cyclin dependent kinases (CDKs), and CDK inhibitors (CDKIs) are key members. The orderly progression through the cell cycle requires sequential activation and inactivation of these modulators. So far, one of the most well studied pathways of cell cycle regulation is that involving $\mathrm{pRB}$, a negative regulator of the G1 to $S$ transition, whose inactivation by different mechanisms, including phosphorylation by upstream elements such as cyclinCDK complexes leads to cell cycle progression and proliferation (fig 1). Alterations in most of the above elements leading to increased proliferative activity have been observed in many different cancer models, including breast carcinomas, both in vivo and in vitro.

\section{Retinoblastoma protein}

The RB gene was the first tumour supressor gene to be discovered and its alteration has been observed in many tumour types. The RB gene can be inactivated by mutation, viral insertion, or deletion and the inactivation of pRB can be achieved by phosphorylation. ${ }^{23}$ In breast cancers, RB loss of heterozygosity (LOH) has been seen in $\sim 25 \%$ of informative cases, but this abnormality does not always correlate with decreased protein synthesis. ${ }^{4}$ Therefore, immunohistochemistry seems to be a better tool to define the concentration (although not the phosphorylation status) of the protein product of this gene. Indeed, we and others have observed an absence or substantial decrease in $\mathrm{pRB}$ synthesis in $10-45 \%$ of infiltrating breast carcinomas, and this downregulation seems to be important for neoplastic progression because it is associated with increased proliferation of tumour cells. ${ }^{5-8}$ Unfortunately, it has not been settled definitively whether the immunohistochemical evaluation of $\mathrm{pRB}$ has prognostic implications in breast carcinomas, because of the differences in methodology and criteria used for assessing $\mathrm{pRB}$ abrogation. The evaluation of the phosphorylation status of the protein has also been proposed as a prognostic tool, ${ }^{9}$ because $\mathrm{pRB}$ controls an important regulatory pathway in G1 in those cases without genetic abnormality, and it is subjected directly to upstream regulators, such as cyclins and CDKs.

\section{Cyclins D1 and E}

Cyclins are proteins that regulate cell cycle specific kinases by direct binding, and are

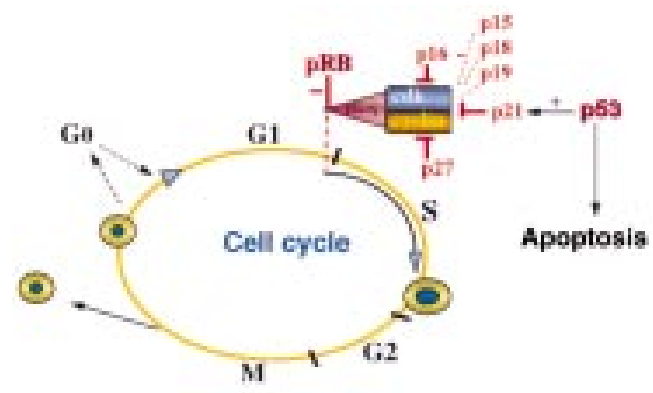

Figure 1 Scheme of cell cycle regulation through the retinoblastoma gene product pathway.
Accepted for publication 28 August 1998 
activated sequentially (cyclin D1 in early G1, cyclin E afterwards), therefore modulating CDK activity and thus stimulating $\mathrm{pRB}$ phosphorylation (inactivation) leading to cell cycle progression. ${ }^{10}$ Among the different cyclins, D1 and $\mathrm{E}$ are probably the most extensively studied in most cancer systems, including breast tumours. ${ }^{11}$

Cyclin D1 is considered to be a weak protooncogene because of its capacity to transform fibroblasts together with activated H-Ras. ${ }^{12}$ In addition, transgenic mice that overexpress the gene encoding this cyclin develop mammary hyperplasia and adenocarcinomas. ${ }^{13}$ Cyclin D1 activation was first observed in parathyroid adenomas as a result of chromosomal inversion involving its locus at $11 \mathrm{q} 13$ and the parathyroid hormone locus at $11 \mathrm{p} 15,{ }^{14}$ and subsequently by chromosomal translocation in some types of lymphomas. ${ }^{15}$ However, in solid tumours, the most frequent mechanisms of cyclin D1 activation are gene amplification and mRNA/ protein overexpression.

Alterations involving cyclin D1 in breast cancers include gene amplification in $\sim 15$ $20 \%$ of cases, ${ }^{16-21}$ and mRNA and/or protein overexpression in $>50 \%$ of cases, ${ }^{6}{ }^{17-23}$ indicating that abnormalities involving this cell cycle regulator can arise at different molecular levels. Interestingly, an association between overexpression of the cyclin D1 gene and hormone receptor expression has been observed consistently in breast tumours ${ }^{6124-27}$ and, moreover, we have observed an association between oestrogen receptor negativity and decreased cyclin D1 mRNA in tumours that do not overexpress cyclin D1. ${ }^{6}$ This is consistent with in vitro experiments that show cyclin D1 upregulation by oestrogens $\mathrm{s}^{28-30}$ as well as downregulation by anti-oestrogens. ${ }^{31}{ }^{32}$ These observations support the hypothesis that one of the mechanisms by which steroids stimulate breast cancer cell proliferation might be through cyclin D1 induction. Unexpectedly, cyclin D1 has been reported recently to activate the oestrogen receptor by physically binding to it, thus upregulating oestrogen mediated transcription of a potentially wide range of targets. ${ }^{33}$ An unexplained issue is why the upregulation of cyclin D1 does not usually correlate with increased proliferation of tumour cells. ${ }^{6}{ }^{24}$ Some authors have postulated that excessive amounts of this product could be toxic to the cell. ${ }^{17}$ Alternatively, it might be hypothesised that upregulation of cyclin D1 occurs in the early steps of tumour development, being then clonally conserved without affecting tumour proliferation, which could then be controlled by other modulators. In this sense, cyclin D1 overexpression has been seen in up to $50-87 \%$ of ductal carcinomas in situ and in cases of atypical ductal hyperplasia. ${ }^{27}{ }^{34}{ }^{35} \mathrm{~A}$ more likely explanation is that the great complexity and variety of modulators of the cell cycle precludes a simplistic assignment of direct proliferating or antiproliferating capability to only one of them.

Because of the technical feasibility of cyclin D1 immunohistochemical evaluation, several groups have attempted to use this assessment as a prognostic tool, and have produced contradictory information. ${ }^{25} 263637$ Given the likely proliferative effect of oestrogen on breast tumour cells through cyclin D1 stimulation, analysis of the effectiveness of anti-oestrogen treatment in cyclin D1 overexpressing tumours might prove fruitful, and it could be hypothesised that cases in which such upregulation is caused by gene amplification might be less responsive to this type of treatment because of its hormone independent activation. So far, in vitro studies have shown that the cytostatic effect of anti-oestrogens is not prevented by cyclin D1 overexpression in breast carcinoma cell lines. ${ }^{38}$

Cyclin $\mathrm{E}$ is a regulatory subunit of $\mathrm{CDK} 2$ and, like cyclin D1, seems also to modulate the G1 to $S$ phase transition through phosphorylation of $\mathrm{pRB}$ as a possible redundant mechanism. ${ }^{739}$ However, recent data suggest that the inactivation of $\mathrm{pRB}$ requires the sequential and complementary action of at least the cyclin D1-CDK4-6 and cyclin E-CDK2 complexes. ${ }^{40}$ Cyclin E activity appears to be regulated in normal cells but its regulation seems to be impaired in breast tumour cells because of the existence of isoforms, which together with $\mathrm{CDK} 2$, can form a kinase complex capable of remaining active throughout the cell cycle. ${ }^{41}$ Cyclin E is overexpressed in a subset of breast carcinomas and this expression usually correlates with low cyclin D1 and oestrogen receptor negativity. ${ }^{72}$ Although long term studies and large series of breast tumours need to be analysed, potentially, the immunohistochemical demonstration of cyclin $\mathrm{E}$ overexpression could be more useful as a prognostic marker than cyclin D1. ${ }^{42}$

\section{CDKIs}

Apart from cyclin-CDK complexes, the progression from $\mathrm{G} 1$ to $S$ phase is regulated by an increasingly recognised number of low molecular weight CDKIs. Currently, CDKIs are grouped into two families: the $\mathrm{p} 16^{\mathrm{INK} 4}-\mathrm{p} 15^{\mathrm{INK} 4 \mathrm{~B}}$ and the $\mathrm{p} 21^{\text {WAF1 }}-\mathrm{p} 27^{\mathrm{KIP} 1}$ families. ${ }^{13}$ Because of their inhibitory activity on cell cycle progression, CDKIs are considered to be potential tumour supressor genes. The first CDKI that was implicated in carcinogenesis was p16, as a result of the existence of frequent gene alterations in different cancer cell lines, but these are rare in primary breast carcinomas. ${ }^{44-49}$ So far, little is known about its expression in vivo in primary breast tumours because immunohistochemical results have been inconsistent, although abnormally low or absent expression of this product is frequent according to some authors. ${ }^{50}$ In this respect, methylation of the gene might account for such types of abnormalities, and this phenomenon seems to occur frequently in breast tumours and other types of cancers. $^{5152}$ Far from clarifying the subject, another recent report finds frequent p16 hypomethylation of primary and metastatic tumours when compared with normal breast tissue, ${ }^{53}$ therefore making the regulation of this tumour supressor gene in normal and cancer mammary cells very controversial. 


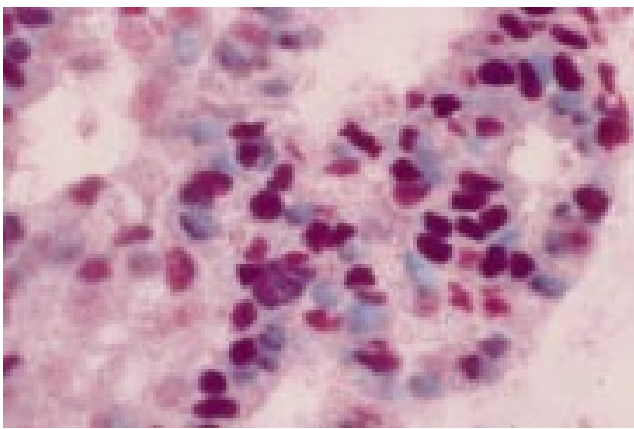

Figure 2 Double immunohistochemical staining for $p 53$ (red) and p21 (blue) in a case of infiltrating ductal carcinoma. Coincidental staining for both markers is seen in the nuclei of several tumour cells (violet).

Haematoxylin/alkaline phosphatase-fast red/beta galactoside-X-gal. ${ }^{59}$

p21 is a CDKI with a wide spectrum of CDK substrates that has been implicated in the mechanisms of cell cycle arrest that allow cell DNA repair. ${ }^{54}$ In this sense, p21 is responsive to wild-type but not mutant $\mathrm{p} 53 .{ }^{55}$ In addition, p21 seems to be related to differentiation in several tumour models including larynx and colon carcinomas. ${ }^{567}$ Although p21 gene mutations are rare, p21 immunohistochemical overexpression is seen frequently in breast carcinomas in which it is associated consistently with high tumour grade, and it is also detected in early stages such as in situ lesions. ${ }^{58-60}$. Interestingly, when p53 protein status is concomitantly analysed, the expression of $\mathrm{p} 21$ seems to be independent of the former, because intense p53 (putatively inactive) and p21 nuclear expression can coexist (fig 2). Contrarily, p21 positive cases frequently overexpress the cyclin D1 gene, ${ }^{59}$ suggesting that, as proposed by Chen et $a l,{ }^{61}$ this CDKI could be involved in cyclin D1 modulation in vivo. The potential prognostic use of p21 expression is not yet clear, because both high and low concentrations of the protein have been related to short survival. ${ }^{58}{ }^{60}$ Similarly to other cell cycle regulators, such as cyclin D1, and other cancer models, the predicted association between the deregulation of $\mathrm{p} 21$ with proliferation has not been demonstrated so far in primary tumours, because p21 downregulation does not correlate with increased proliferation. ${ }^{58} 59$

p27 is one of the latest cell cycle related proteins to come into the spotlight because of its potential strength to predict outcome in several types of tumours, such as stomach and breast carcinomas. This protein effectively induces cell cycle arrest and decreases cyclinCDK activity in breast cancer cell lines. ${ }^{62}$ In addition, and like other members of the CIP/KIP family including p21 and p57, p27 has a role in assembling and targeting CDK4 and cyclin D1 to the nucleus. ${ }^{63}$ p27 is underexpressed frequently in breast carcinomas, and such underexpression seems to be associated with poor prognosis and a more aggressive phenotype. ${ }^{64-66}$ How this gene is downregulated in these neoplasms is not clear, but p27 genomic alterations seem to be rare events in human neoplasms, ${ }^{67} 68$ and posttranscriptional mechanisms have been proposed. ${ }^{666970} \mathrm{~A}$ relation between hormone

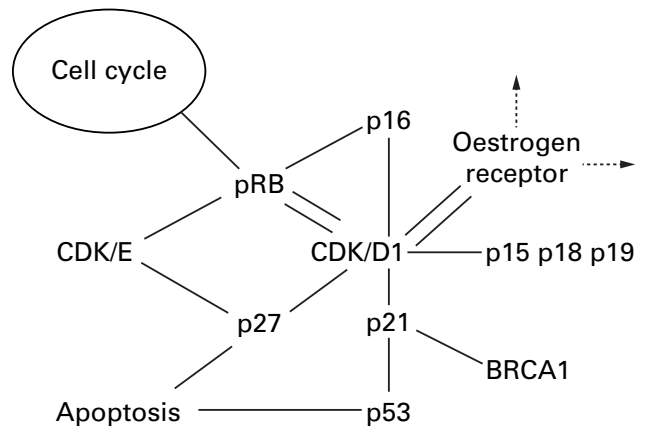

Figure 3 Scheme of some proposed interplays between cell cycle regulators. Double lines indicate regulatory loops and feedback mechanisms. Single lines can indicate either a stimulatory or an inhibitory association.

stimuli and the expression of the gene was shown in breast carcinoma cell lines in which anti-oestrogen administration not only decreased expression of the cyclin D1 gene, but also the increased expression of the genes encoding p27 and p21,32 which could possibly explain some of the therapeutic effects of hormone treatment.

\section{Interplay between cell cycle regulators}

From all the above, it is clear that the regulatory pathways of the progression through the cell cycle of both normal and tumour cells are by no means simple. ${ }^{71}$ The discovery of new modulators (p15, p18, p19, p57, CDKs, etc.), whose inclusion in this review would require extensive data, causes the scheme to be redrawn continuously in a more complicated manner. In addition, it is not only the great number of modulators, but also the existence of increasingly more complex interplays among them, which further precludes a simplistic approach. For example, it is now known that $\mathrm{pRB}$ can regulate expression of the genes encoding cyclin D1 and p16 in cell lines, thus creating complex autoregulatory loops. ${ }^{72-74}$ Studies in primary breast tumours have shown that there is an inverse relation between $\mathrm{pRB}$ and p16 synthesis. ${ }^{5}$ Yet, it can be speculated that tumours lacking $\mathrm{pRB}$ function will have no advantage in concomitant alterations in other regulators like cyclin D1 and p16, whereas such abnormalities could interact to enhance tumour proliferation provided a normal $\mathrm{pRB}$ function. ${ }^{75}$

As mentioned before, cyclin D1 is not only involved in direct cell cycle activation, but it has also been proposed to activate the oestrogen receptor by physically binding to it, thus upregulating oestrogen mediated transcription. ${ }^{33}$ Therefore, cyclin D1 may be regulated by a positive feedback loop. Another perplexing proposal is the possibility that $\mathrm{p} 53$, through $\mathrm{p} 21$, can induce cyclin D $1,{ }^{61}$ thus linking the apoptotic pathway to cell cycle regulation (fig 3), a link strengthened by the possible apoptosis promoting activity of p27 in cancer cell lines. ${ }^{76}$ The possible upregulation of the gene encoding p 27 by cyclin $\mathrm{E}^{77}$ helps to create complex regulatory feedbacks mechanisms involving CDKIs. Finally, it has been reported recently that the hereditary breast and ovarian cancer related tumour supressor 
gene BRCA1 might contribute to cell cycle arrest and growth suppression through the induction of $\mathrm{p} 21^{78}$

Therefore, it seems that a kind of "regulatory web" with complex regulatory positive and negative feedbacks mechanisms and interconnections regulates cell cycle progression, and probably other cell functions (fig 3). Such complexity will most likely call into question the future value of the assessment of individual tumour markers for prognostic and therapeutic purposes, and it could be hypothesised that the assessment of the integrity of specific entwined pathways will be required.

We thank Dr M Sobel for reviewing the manuscript. This work was supported by grants FIS 93/1012 of the Fondo de Investiwas supported by grants FIS 93/1012 of the Fondo de Investigaciones Sanitarias, Ministerio de Sanidad, Marató-Ca

1 Grana X, Reddy EP. Cell cycle control in mammalian cells: role of cyclins, cyclin dependent kinases (CDKs), growth supressor genes and cyclin-dependent kinase inhibitors (CKIs). Oncogene 1995;11:211-19.

2 Weinberg RA. The retinoblastoma protein and cell cycle control. Cell 1995;81:323-30.

3 Jansendurr P. How viral oncogenes make the cell cycle. Trends Genet 1996;12:270-5.

4 Borg A, Zhang QX, Alm P, et al. The retinoblastoma gene in breast cancer: allele loss is not correlated with loss of gene protein expression. Cancer Res 1992;52:2991-4.

5 Dublin EA, Patel NK, Gillet CE, et al. Retinoblastoma and p16 proteins in mammary carcinoma: their relationship to cyclin D1 and histopathological parameters. Int $\mathcal{F}$ Cancer 1998;79:71-5.

6 Jares P, Rey MJ, Fernandez PL, et al. Cyclin D1 and retinoblastoma gene expression in human breast carcinoma: correlation with tumour proliferation and oestrogen receptor relation with tumour proliferation
status. F Pathol 1997;182:160-6.

7 Nielsen NH, Emdin SO, Cajander J, et al. Deregulation of cyclin E and D1 in breast cancer is associated with inactivation of the retinoblastoma protein. Oncogene 1997;14: 295-304.

8 Trudel M, Mulligan L, Cavenee W, et al. Retinoblastoma and $\mathrm{p} 53$ gene product expression in breast carcinoma: immunohistochemical analysis and clinicopathologic correlation. Hum Pathol 1992;23:1388-94

9 Wakasugi E, Kobayashi T, Tamaki Y, et al. Analysis of phosphorylation of $\mathrm{pRB}$ and its regulatory proteins in breast cancer. F Clin Pathol 1997;50:407-12.

10 Hunter T, Pines J. Cyclins and cancer. II. Cyclin D and CDK inhibitors come of age. Cell 1994;79:573-82.

11 Landberg G, Roos G. The cell cycle in breast cancer. APMIS 1997; 105:575-89.

12 Lovec H, Sewing A, Lucibello FC, et al. Oncogenic activity of cyclin D1 revealed through cooperation with Ha-ras: link between cell cycle control and malignant transformation. between cell cycle control

13 Wang TC, Cardiff RD, Zukerberg L, et al. Mammary hyperplasia and carcinoma in MMTV-cyclin D1 transgenic plasia and carcinoma in MM

14 Arnold A, Kim HG, Gaz RD, et al. Molecular cloning and chromosomal mapping of DNA rearranged with the parathyroid hormone gene in a parathyroid adenoma. $\mathcal{F}$ Clin Invest 1989;83:2034-40.

15 Rosenberg CL, Wong E, Petty EM, et al. PRAD1, a candidate BCL1 oncogene: mapping and expression in centrocytic lymphoma. Proc Natl Acad Sci USA 1991;88: 9638-42.

16 Fantl V, Smith R, Brookes S, et al. Chromosome 11q13 abnormalities in human breast cancer. Cancer Surv 1993;18:77-94.

17 Gillet C, Fantl V, Smith R, et al. Amplification and overexpression of cyclin D1 in breast cancer detected by immunohistochemical staining. Cancer Res 1994;54:1812imm.

18 Shuuring E, Verhoeven E, Tinteren $\mathrm{H}$, et al. Amplification of genes within the chromosome $11 \mathrm{q} 13$ region is indicative of poor prognosis in patients with operable breast cancer. Cancer Res 1992;52:5229-34.

19 Dickson C, Fantl V, Gillett C, et al. Amplification of chromosome band $11 \mathrm{q} 13$ and a role for cyclin D1 in human breast cancer. Cancer Lett 1995;90:43-50.

20 Bates S, Peters G. Cyclin D1 as a cellular proto-oncogene. Cancer Biol 1995;6:73-82.

21 Worsley SD, Jennings BA, Khalil KH, et al. Cyclin D1 amplification and expression in human breast carcinoma:
correlation with histological prognostic markers and oestrogen receptor expression. 7 Clin Pathol: Mol Pathol 1996;49:M46.

22 Zhang S, Caamano J, Cooper F, et al. Immunohistochemistry of cyclin D1 in human breast cancer. Am F Clin Pathol 1994;102:695-8.

23 Bartkova J, Lukas J, Muller H, et al. Cyclin D1 protein expression and function in human breast cancer. Int $\mathcal{F}$ Cancer 1994;57:353-61.
24 Zukerberg LR, Yang WI, Gadd M, et al. Cyclin D1 (PRAD1) protein expression in breast cancer: approxioverexpression of the cyclin D1 oncogene. Mod Pathol 1995;8:560-7.

25 Michalides R, Hageman P, van Tinteren H, et al. A clinicopathological study on overexpression of cyclin D1 and of p53 in a series of 248 patients with operable breast cancer. Br f Cancer 1996;73:728-34.

26 van Diest PJ, Michalides RJ, Jannink L, et al. Cyclin D1 expression in invasive breast cancer. Correlations and prognostic value. Am F Pathol 1997;150:705-11.

27 Gillet CE, Lee AHS, Millis RR, et al. Cyclin D1 and associated proteins in mammary ductal carcinoma in situ and atypical ductal hyperplasia. f Pathol 1998;184:396-400.

28 Sutherland RL, Watts CKW, Musgrove EA. Cyclin gene expression and growth control in normal and neoplastic 47:99-106.

29 Altucci L, Addeo R, Cicatiello L, et al. 17ß-Estradiol induces cyclin D1 gene transcription, p36D1-p34cdk4 complex activation and $\mathrm{p} 105 \mathrm{Rb}$ phosphorylation during mitogenic stimulation of $\mathrm{G}(1)$-arrested human breast cancer cells. Oncogene 1996;12:2315-24.

30 Prall OWJ, Sarcevic B, Musgrove EA, et al. Estrogeninduced activation of Cdk4 and Cdk2 during G1-S phase progression is accompanied by increased cyclin D1 expression and decreased cyclin-dependent kinase inhibitor $10882-94$.

31 Musgrove EA, Hamilton JE, Lee CSL, et al. Growth factor, steroid, and steroid antagonist regulation of cyclin gene expression associated with changes in T-47D human breast cancer cell cycle progression. Mol Cell Biol 1993;13:3577-

32 Watts CK, Brady A, Sarcevic B, et al. Antiestrogen inhibition of cell cycle progression in breast cancer cells is associated with inhibition of cyclin-dependent kinase activity and decreased retinoblastoma protein phosphorylation. Mol Endocrinol 1995;9:1804-13.

33 Zwijsen RM, Wientjens E, Klompmaker R, et al. CDK-independent activation of estrogen receptor by cyclin D1. Cell 1997;88:405-15.

34 Weinstat-Saslow D, Merino MJ, Manrow RE, et al. Overexpression of cyclin D mRNA distinguishes invasive and in situ breast carcinomas from non-malignant lesions. Nat Med 1995;1:1257-60.

35 Simpson JF, Quan DE, O'Malley F, et al. Amplification of CCND1 and expression of its protein product, cyclin D1, in ductal carcinoma in situ of the breast. Am F Pathol 1997; 151:161-8.

36 McIntosh GG, Anderson JJ, Milton I, et al. Determination of the prognostic value of cyclin D1 overexpression in breast cancer. Oncogene 1995;11:885-91.

37 Pelosio P, Barbareschi M, Bonoldi E, et al. Clinical significance of cyclin D1 expression in patients with nodepositive breast carcinoma treated with adjuvant therapy. Ann Oncol 1996;7:695-703.

38 Pacilio C, Germano D, Addeo R, et al. Constitutive overexpression of cyclin D1 does not prevent inhibition of hormone-responsive human breast cancer cell growth by hormone-responsive human breast cancer

39 Gray-Bablin J, Zalvide J, Fox MP, et al. Cyclin E, a redundant cyclin in breast cancer. Proc Natl Acad Sci USA 1996; 93:15215-20

40 Lundberg AS, Weinberg RA. Functional inactivation of the retinoblastoma protein requires sequential modification by at least two distinct cyclin-cdk complexes. Mol Cell Biol 1998;18:753-61.

41 Keyomarsi K, Conte D Jr, Toyofuku W, et al. Deregulation of cyclin E in breast cancer. Oncogene 1995;11:941-50.

42 Nielsen NH, Arnerlov C, Emdin SO, et al. Cyclin E overexpression, a negative prognostic factor in breast cancer with strong correlation to oestrogen receptor status. Br $\mathcal{F}$ Cancer 1996;74:874-80.

43 Sherr CJ, Roberts JM. Inhibitors of mammalian G1 cyclindependent kinases. Genes Dev 1995;9:1149-63.

44 Serrano M, Hannon GJ, Beach D. A new regulatory motif in cell-cycle control causing specific inhibition of cyclin D/CDK4. Nature 1993;366:704-7.

45 Kamb A, Gruis NA, Weaver-Feldhaus J, et al. A cell cycle regulator potentially involved in genesis of many tumor types. Science 1994;264:436-40.

46 Nobori T, Miura K, Wu DJ, et al. Deletions of the cyclin-dependent kinase-4 inhibitor gene in multiple human cancers. Nature 1994;368:753-6.

47 Xu L, Sgroi D, Sterner CJ, et al. Mutational analysis of CDKN2 (MTS1/p16ink4) in human breast carcinomas. Cancer Res 1994;54:5262-4.

48 Musgrove EA, Lilischkis R, Cornish AL, et al. Expression of the cyclin-dependent kinase inhibitors p16INK4, p15INK4B and p21WAF1/CIP1 in human breast cancer. Int $\mathcal{F}$ Cancer 1995;63:584-91.

49 Calvano JE, Rush EB, Tan LK, et al. Absence of p16 gene CDKN2) deletions in microdissected primary breast carcinma pecimens. Ann Surg Oncol 1997;4:416-20.

50 Geradts J, Wilson PA. High frequency of aberrant p16 (INK4A) expression in human breast cancer. Am f Pathol 1996;149:15-20.

51 Herman JG, Merlo A, Mao L, et al. Inactivation of the CDKN2/p16/MTS1 gene is frequently associated with aberrant DNA methylation in all common human cancers. Cancer Res 1995;55:4525-30. 
52 Foster SA, Wong DJ, Barret MT, et al. Inactivation of p16 in human mammary epithelial cells by $\mathrm{CpG}$ island

53 Van Zee KJ, Calvano JE, Bisogna M. Hypomethylation and increased gene expression of p16INK4a in primary and metastatic breast carcinoma as compared to normal breas tissue. Oncogene 1998;16:2723-7.

$54 \mathrm{Li}$, Waga S, Hannon GJ, et al. Differential effects by the p 21 CDK inhibitor on PCNA-dependent DNA replication and repair. Nature 1994;371:534-7.

55 El-Deiry WS, Tokino T, Velculescu VE, et al. Waf1, a potential mediator of p53 tumor suppression. Cell 1993;75: 817-25.

56 Nadal A, Jares P, Cazorla M, et al. P21/WAF1/Cip1 expression is associated with cell differentiation but not with p53 mutations in squamous cell carcinomas of the larynx. $f$ Pathol 1997;183:156-63.

57 Doglioni C, Pelosio P, Laurino L, et al. p21/WAF/CIP1 expression in normal mucosa and adenocarcinoma of the colon: its relationship with differentiation. $f$ Pathol colon: its relation

58 Barbareschi M, Caffo O, Doglioni C, et al. p21WAF1 immunohistochemical expression in breast carcinoma: correlations with clinicopathological data, oestrogen receptor status, MIB1 expression, p53 gene and protein alterations and relapse-free survival. Br F Cancer 1996;74:208-15.

59 Rey MJ, Fernández PL, Jares P, et al. P21/WAF1/Cip1 is associated with cyclin D1/CCND1 expression and tubula differentiation but is independent of $\mathrm{p} 53$ overexpression in human breast carcinoma. F Pathol 1998;184:265-71.

60 Jiang M, Shao ZM, Wu J, et al. p21/waf1/cip1 and mdm-2 expression in breast carcinoma patients as related to prognosis. Int $\mathcal{F}$ Cancer 1997;74:529-34.

61 Chen X, Bargonetti J, Prives C. p53, through p21(waf/ cip1), induces cyclin D1 synthesis. Cancer Res 1995;55: 4257-63.

62 Craig C, Wersto R, Kim M, et al. A recombinant adenovirus expressing $\mathrm{p} 27 \mathrm{Kip} 1$ induces cell cycle arrest and loss of cyclin-Cdk activity in human breast cancer cells. of cyclin-Cdk activity 19

$63 \mathrm{LaBaer}$ J, Garrett MD, Stevenson LF, et al. New functional activities for the p21 family of CDK inhibitors. Genes Der activities for the p21

64 Tan P, Cady B, Wanner M, et al. The cell cycle inhibitor p27 is an independent prognostic marker in small $(\mathrm{t} 1 \mathrm{a}, \mathrm{b})$ invasive breast carcinomas. Cancer Res 1997;57:1259-63.

65 Catzavelos C, Bhattacharya N, Ung YC, et al. Decreased levels of the cell-cycle inhibitor p27Kip1 protein: prognostic implications in primary breast cancer. Nat Med 1997;3 227-30.
66 Fredersdorf S, Burns J, Milne AM, et al. High level expression of p27(kip1) and cyclin D1 in some human breast cancer cells: inverse correlation between the expression of p27(kip1) and degree of malignancy in human breast and colorectal cancers. Proc Natl Acad Sci USA 1997;94:63805.

67 Ferrando AA, Balbin M, Pendas AM, et al. Mutational analysis of the human cyclin-dependent kinase inhibitor 27kip1 in primary breast carcinomas. Hum Genet 197kip 1 in $97: 91-4$.

68 Ponce-Castañeda MV, Lee M, Latres E, et al. p27/Kip1: chromosomal mapping to $12 \mathrm{p} 12-12 \mathrm{p} 13.1$ and absence of mutations in human tumors. Cancer Res 1995;55:1211-14.

69 Hengst L, Reed SI. Translational control of p27kip1 accumulation during the cell cycle. Science 1996;271:1861-4.

70 Loda M, Cukor B, Tam SW, et al. Increased proteasomedependent degradation of the cyclin-dependent kinase nhibitor p27 in aggressive colorectal carcinomas. Nat Med 1997;3:231-4.

71 Jacks T, Weinberg RA. The expanding role of cell cycle regulators. Science 1998;280:1035-6.

72 Muller H, Lukas J, Schneider A, et al. Cyclin D1 expression is regulated by the retinoblastoma protein. Proc Natl Acad Sci USA 1994;91:2945-9.

73 Lukas J, Muller H, Bartkova J, et al. DNA tumor virus oncoproteins and retinoblastoma gene mutations share the ability to relieve the cell's requirement for cyclin D1 function in G1. F Cell Biol 1994;125:625-38.

74 Li Y, Nichols MA, Shay JW, et al. Transcriptional repression of the D-type cyclin-dependent kinase inhibitor p16 by the retinoblastoma susceptibility gene product $\mathrm{pRb}$. Cancer Res 1994;54:6078-82.

75 Lukas J, Aagaard L, Strauss M, et al. Oncogenic aberrations of p16INK4/CDKN2 and cyclin D1 cooperate to deregulate G1 control. Cancer Res 1995;55:4818-23.

76 Katayose Y, Kim M, Rakkar ANS, et al. Promoting apoptosis: a novel activity associated with the cyclindependent kinase inhibitor p27. Cancer Res 1997;57:5441-

77 Sgambato A, Han EK, Zhou P, et al. Overexpression of cyclin $\mathrm{E}$ in the HC11 mouse mammary epithelial cell line is associated with growth inhibition and increased expression of p27(Kip1). Cancer Res 1996;56:1389-99.

78 Somasundaram K, Zhang H, Zeng YX, et al. Arrest of the cell cycle by the tumour-supressor BRCA1 requires the CDK-inhibitor p21WAF1/CIP1. Nature 1997;389:187-90. 